\title{
NOTCH3 wt Allele
}

National Cancer Institute

\section{Source}

National Cancer Institute. NOTCH3 wt Allele. NCI Thesaurus. Code C106437.

Human NOTCH3 wild-type allele is located within 19p13.2-p13.1 and is approximately 41

$\mathrm{kb}$ in length. This allele, which encodes neurogenic locus notch homolog protein 3 , is

involved in both cell-cell signaling and cell differentiation. Mutation of the gene is

associated with cerebral autosomal dominant arteriopathy with subcortical infarcts and leukoencephalopathy (CADASIL). 